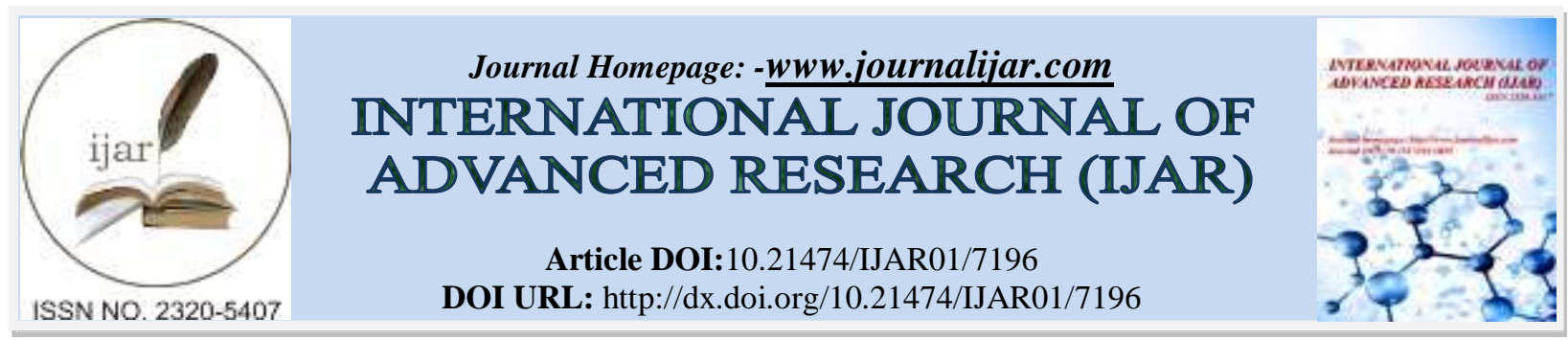

RESEARCH ARTICLE

\title{
DEVELOPMENT OF TRAINING MODEL OF HEAD OF MADRASAH ALIYAH IN EDUCATION HALL AND RELIGIOUS TRAINING SEMARANG
}

Suwardi.

The Ministry of Religion, Education Hall and Religious Training Semarang, Republic of Indonesia.

\section{Manuscript Info}

Manuscript History

Received: 03 April 2018

Final Accepted: 05 May 2018

Published: June 2018

Keywords:-

training model, education, religious.

\begin{abstract}
The training model is the driving force in the effort of developing the ability of rational thinking and good personility with high interity will bi the burden of office mandate there fore, educational programs training in government agencies, should be a big concern, so that later can be an important point to improve employee performance. This study uses descriptive research approach, which aims to describe the systematic, factual and accurate about the facts, properties and the relationship between the phenomena investigated. Employee development system implemented by Balai Education and Religious Training Semarang based on observations of researchers, there are several considerations and requirements that include: 1) System development in optimizing the increase in productivity of employees is working to improve the atmosphere of organizations / agencies in the form of mastery skills and implementation techniques work so that the development of an employee is considered very important; 2) Employee development system implemented through Education Hall and Training gives a good response from employees that institutions / agencies really pay attention to the need for employees in the implementation of work and responsibilities that have been submitted to him; and 3) Employees are motivated to carry out their work and strive to increase their work productivity in the light of the development given to it. The achievement of information about the Training and Training Center in Central Religious Education and Training Semarang in pacuced by over transmission factors, clarity and consistent.
\end{abstract}

Copy Right, IJAR, 2018,. All rights reserved. 
Improving the quality of Human Resources (HR) needs to get more attention. The government is obliged to increase human resources, especially Government Employees (PNS / Pegawai Negri Sipil). One of the efforts to improve the human resources is through education and training. Government Regulation number 11 of 2017 on the training of government officials explained that the training consists of two types of pre-service training and in-service training. Preparatory training consists of preemployment training class I, II, and III. This refers when the participant is still a CPNS (Candidate for Government Employees). In-Service Training Activities consists of three types of training. The three types of training include leadership training, technical training, and functional training.

The development of human resources and mentoring can be done through education and training. According to I Komang Ardana et al (2012: 91), development is an attempt to improve the technical, theoretical, conceptual and moral skills of employees in accordance with the needs of jobs / occupations through education and training. Education enhances the theoretical, conceptual and moral skills of employees, while the exercise aims to improve the technical skills of employee job implementation. Improving the quality of staff through education and training should be undertaken. For government employees in the Ministry of Religious Affairs, the implementation of the training is carried out by the Research and Development Agency and Training of the Ministry of Religious Affairs. Implementation of the training is on the Administrative Training Center, Training Center for Technical and Religious Education, and Religious Training Center. Especially for education and religion carried out by Technical Training Center and Religious. PMA Number 75 of 2015 Article 27 explains that the Center for Technical and Religious Training is a Training Institution at the Ministry of Religious Affairs which has the duty to organize the Education and Religious Technical Education training.

Therefore the ministry of religion is also responsible for organizing religious education called madrasah. According to the PMA number 29 of 2014 madrasah is a unit of formal education in the guidance of the Minister of Religious Affairs that holds general and vocational education with Islamic religious peculiarities that include Raudhotul Athfal (RA), Madrasah Ibtidaiyah (MI), Madrasah Tsanawiyah (MTs), Madrasah Aliyah (MA) and Madrasah Aliyah Kejuruan (MAK). Each level has a leader called the principal of madrasah.

According to PMA number 29 of 2014 the principal of madrasah must have competence: (1) personality; (2) managerial; (3) entrepreneurship; (4) supervision; and (5) social, in order to have such competence, the Ministry of Religious Affairs through the Religious Training Center organizes education and training which is called substantive technical training of additional training of madrasah principal. ${ }^{1}$

In thedevelopment of Training today has lead to what is needed? Is the proposed design most appropriate? Is the training done the most appropriate? How do we know the results achieved in the future? So many questions that need to be asked both before and after the training is done, then the training has to be managed well, because generally responsible in planning, implementation, development and training, performance appraisal, development harmonious relationships, moral development and maintenance and a number of other related activities.

Conducting a quality training model requires the guidance and services of human resources specialists. Training will make human resources more valuable not only for themselves but also necessary for others around them, of course, organized effectively and efficiently.

In relation to this theme, the authors of the scientific papers present important points that are related to the development of education and training of Madrasah principals as follows, how the model of training and how the development of the training model related to the training that has been carried out in the training the comparative training between what has been done and at the time and its evaluation and how is the development of education and training model of Madrasah Principal in ReligiousTraining Center of Semarang?

\section{Problem Formulation}

The author examines and examines the development of the model of Education and Training of Madrasah Aliyah Principals at the Religious Training Center of Semarang. The problem formulation of scientific paper in this research is:

a. How to model the training and development of the training model related to the training in the Religious Training Center of Semarang?

\footnotetext{
${ }^{1}$ Peraturan Menteri Agama Republik Indonesia Nomor 29 Tahun 2014 tentang Kepala Madrasah.
} 
b. How to develop a Madrasah Principal Training Model at Religious Training Center of Semarang ?

\section{Problem Solving}

The purpose of this paper is to provide an overview of the development of Madrasah Aliyah Principal Training Model in the Ministry of Religious Affairs of Central Java Province and the Special Province of Yogjakarta following the training at the Central Religious Training Center of Semarang, is:

a. To know and analyze the model of training and development of the training model at Religious Training Center of Semarang.

b. To analyze the development of the training model a MadrasahPrincipal Training Model at Religious Training Center of Semarang.

\section{Benefits of the Study}

This research is expected to provide benefits for all also concerned in this scientific paper, 1), Benefits practically for the makers of scientific papers, this scientific paper can add knowledge and insight on the development of education model and training principal Madrasah Aliyah, including for readers, this research can provide information in writing and as a reference about the development of learning process Education and Training of Madrasah Aliyah principals at the Office of Education and Religious Training Center of Semarang. As for 2). The theoretical benefit for the scholar of scientific writing can contribute to the mentors as producers who are productive and innovative in the field of scientific development.

For training, this scientific paper can contribute thoughts and references to the training as a manager and user of sincerity in the development of effective management of the creative, including for the scientific paper writer can contribute thoughts and references for educators in the field of education development and training of Madrasah principals in Religious Training Center of Semarang.

To know related to the development of learning process of education and training of MadrasahAliyah principal at the Office of Education and Religious Training Center of Semarang.

\section{B. WRITING METHOD}

Based on the background of study, problem formulation and the purpose of writing scientific papers, the scientific writing, the author uses two methods of quantitative methods and qualitative methods are: a) Quantitative and qualitative methods are often paired with the name of traditional methods and new methods; positivistic methods and postpositivistic methods, scientific and artistic methods, confirmation methods and findings. Quantitative methods are often called traditional, positivistic, scientific and discovery methods. b) Furthermore, qualitative methods are often referred to as new methods, postposivistic, artistic and interpretive research. Qualitative research method is named as a new method because of its popularity not long ago, this method is called postpositivistic, because it is based on post positiveism philosophy. This method is also called artistic method, because the research process is more artistic (less patterned), and is called the interpretive method because the data of the research is more related to the interpretation of the data found in the field.

The qualitative research of the researcher is based on the data, using the existing theory as the explanatory material, and ending with a "theory". From the point of view of qualitative research proceeding inductively, the process begins with the effort to obtain detailed data (curriculum vitae of respondent, life story, life sycle), without evaluation and interpretation, then in categories, abstractions and themes, concepts or theories as a finding. Through literature review and data collection both primary and secondary regulatory policy policies concerning authenticity.

\section{THEORITICAL REVIEW}

1. The Meaning of Development

First will be explained about the definition of the model of training, the model is something that describes the pattern of thinking. A model usually describes a whole concept of interrelatedness. In other words the model can also be seen as an attempt and to concoct a theory as well as an analogue and representation of the variables contained in the theory. ${ }^{2}$

\footnotetext{
${ }^{2}$ Benny A. Pribadi,2010, Model Desain Sistem Pembelajaran, Jakarta: Dian Rakyat, p. 86.
} 
According to Robins, "A model is an abstraction of reality; a simplified representation of some real-world phenomenon." 3 The purpose of the definition, the model is a representation of some phenomena that exist in the real world. The definition of the model is also expressed by Miarso ie the model is a representation of a process in the form of graphics and / or narrative, by showing the main elements and structure. In this case it is possible to interpret the narrative model into graphic form, or vice versa. ${ }^{4}$

Development is defined as the preparation of individuals to assume different or higher responsibilities within an enterprise, organization, institution or educational institution.

The meaning of training and development is different. Training is aimed at improving the mastery of certain skills and techniques of job implementation, detailed and routine, ie training preparing the employees (labor) to do the work now, while the development has a wider scope in an effort to improve and enhance knowledge, abilities, attitudes and personality traits. ${ }^{5}$

Development tends to be more formal, concerning the anticipation of the ability and the individual's skill that must be prepared for the interests of the position that will come. Goals and development programs involve a broader aspect of enhancing the ability of individuals to anticipate changes that may occur without being planned (unplaned change) or planned change. ${ }^{6}$

\section{The Meaning of the Training}

Training is a learning process that involves acquiring skills, concepts, rules, or attitudes to improve the performance of ape monkeys. ${ }^{7}$ According to article I paragraph 9 of the law No.13 of 2003. Job training is the whole activity to give, gain, improve, and develop work competence, productivity, discipline, attitude, work ethos at a certain level of skills and expertise in accordance with the level and qualifications of position and occupation.

Raising training is every effort to improve the worker's performance on a particular job that is the responsibility. According to him the term training is often equated with the term development, the difference is that direct training is related to job performance on the current job, whereas development is not necessarily, development has a wider skcope than training. ${ }^{8}$

Training is more focused on improving the skills and expertise of the organization's human resources related to the position or function that is the responsibility of the current individual concerned (current job oriented). The goal to be achieved and a training program is the improvement of individual performance in the current position or function. Similarly, Hadari pointed out that there are training programs to improve the ability to carry out work individually, group and / or based on the level of position in the organization or company. While career development is a formal and sustainable business with focus on improving and adding the ability of a worker. This understanding shows that the focus of career development is the improvement of the mental ability of the workforce.

In terms of training and development refers to the total structure and programs in and out of employee work that the company exploits in developing skills and knowledge, primarily for job performance and career promotion. Usually training refers to the development of vocational skills that can be used immediately. ${ }^{9}$

\footnotetext{
${ }^{3}$ Stephen P. Robins, 1996, Organizational Behavior: Concepts, Controversies, Applications, New York: Prentice Hall, Inc., p. 25.

${ }^{4}$ Yusuf Hadi Miarso, 2011, "Survei Model Pengembangan Instruksional”, makalah yang disampaikan sebagai bahan ajar kuliah mahasiswa S3 Program Studi Teknologi Pendidikan Pascasarjana UNJ.

${ }^{5}$ Hani Handoko, 2001, Manajemen Personalia dan Sumber Daya Manusia, edisikedua, Yogyakarta: BPFE, p. 104.

${ }^{6}$ Syafaruddin Alwi, 2001, Manajemen Sumber Daya Manusia, Strategi Keunggulan Kompetitif, Yogyakarta: BPFE, p. 217.

${ }^{7}$ Henry Simamora, 2006, Manajemen Sumber Daya Manusia, edisi 2, Yogyakarta: STIE YKPN, p. 273.

${ }^{8}$ Faustino Cardoso Gomes, 2003, Manajemen Sumber Daya Manusia, Yogyakarta: Andi Offset, p. 197.

${ }^{9}$ Sjafri Mangkuprawira, 2003,Manajemen Sumber Daya Manusia Stratejik, cetakan ke-2, Jakarta: Ghalia Indonesia, p. 135.
} 


\section{Meaning Of Madrasah Principal}

The principal of madrasah comes from two words: principal and madrasah. The word principal can mean "chairman" or leader in an organization or an institution. While madrasah in terms of language is the school, and madrasah in terms of the term is an educational institution where a place to receive and give lessons.

In a simple way, the principal of a madrasah can be defined as a functional teacher who is assigned to lead a madrasah where the learning process is organized or where interaction occurs between the teacher of the lesson and the student receiving the lesson. ${ }^{10}$

\section{Duties of Madrasah Principal}

The principal of a madrasah is essentially a teacher who is given an additional assignment. Madrasah principal is one of the most important components of education in improving the quality of education. Mulyasa states that; "Closely related to the quality of Madrasah Principals with various aspects of madrasah life such as madrasah discipline, and madrasah climate". The principal of a madrasah should be able to create a conducive and innovative atmosphere in carrying out activities in madrasah. This is in accordance with the Minister of National Education Regulation No. 13 of 2007 on Principal / Madrasah Standards, stated that "The principal of madrasah manages teachers and staff in optimum utilization of human resources, creating a conducive and innovative madrasah culture and climate for learning". 11

Principal of madrasah must have vision, mission, creative and innovative and quality oriented. This strategy is a systematic effort of Madrasah Principals continuously to improve the quality of services so that the focus is directed to teachers and other education personnel so that the educational institutions they lead can run well. As a leader in the madrasah, the roles and responsibilities of Madrasah principals are very strategic in improving the performance of teachers and other education personnel. The role and function of Madrasah principal in improving teacher performance is very important. This is in line with Mulyasa's opinion that: "Madrasah principals are required to constantly develop and develop good cooperative relationships between madrasah and the community in order to realize effective and efficient madrasah. Principal of madrasah should be able to establish cooperation relationships between fellow madrasah and madrasah community environment ". ${ }^{12}$

From the above quote can be concluded that the principal of Madrasah to communicate with subordinates to improve the performance and quality of work. Through a good partnership, the function of the Madrasah Principal as an innovator and motivator has an appropriate strategic role to establish a harmonious communication with the environment, to seek new ideas, to integrate each activity, to model all teachers in the madrasah he leads. As a leader, the madrasah principal should also have the right strategy to motivate the teacher in carrying out his duties and functions. This motivation can be grown through good environmental arrangement, conducive atmosphere arrangement and communicative, synergistic discipline among component of madrasah. Some principles that can be applied by the principal of madrasah schools in improving the performance of teachers as educational personnel in order to improve their professional skills. These principles as mentioned by E. Mulyasa are as follows:

a. Teachers will work harder if the activities are interesting and fun.

b. The purpose of the activity needs to be clearly defined and informed to the education personnel so that they know the purpose of the work.

c. The education personnel should also be involved in the preparation of these goals.

d. The education personnel should always be informed about the outcome of each job. Giving a reward is better than punishment but at any time punishment also needs to be done.

e. For the needs of educational personnel can be done with attention to physical condition, provide a sense of security, indicating that the principal madrasah to pay attention to them, set the experience in such a way that each employee to get satisfaction in the job. ${ }^{13}$

The meaning of the Madrasah Principal is defined as a functional teacher who is assigned to lead a madrasah where the learning process is organized. ${ }^{14}$ The English leader is called the 'leader' of the root to the word which is closely

\footnotetext{
${ }^{10}$ Wahyusumiyo, 2002, Kepemimpinan Kepala Sekolah, Jakarta: PT Raja Grafindo Persada, p. 81.

${ }^{11}$ Mulyasa, E., 2012, Manajemen dan Kepemimpinan Kepala Sekolah, Jakarta: Bumi Aksara, p. 24.

${ }^{12}$ Ibid., p. 187.

${ }^{13}$ Ibid., p. 121-122.
} 
related: moving earlier, walking ahead, taking the first step, doing the very first, pioneering, directing thoughts of other people's actions, guiding, guiding, moving others through its influence. Furthermore, the author will explain the definition of leadership according to experts. The definition of leadership that experts present varies from one to the other. Hoy and Miskol, as quoted Purwanto, argue that the definition of leadership is almost as much as those who research and define it. ${ }^{15}$

Leadership is an activity in guiding a group in such a way that the goals of the group are achieved. ${ }^{16}$ The principal of madrasah comes from two words: principal and madrasah. The word principal can mean "chairman" or leader in an organization or an institution. While madrasah in terms of language is the school, and madrasah in terms of the term is an educational institution where a place to receive and give lessons. ${ }^{17}$ According to Wahjosumidjo, simply the principal of a madrasah (school) can be defined as a functional teacher who is assigned to lead a madrasah (school) where a teaching-learning process takes place, or a place where there is an interaction between the teacher giving the lesson and the student receiving the lesson ${ }^{18}$ So the conclusion that the principal of a madrasah (school) is someone who is assigned by his subordinates to lead a madrasah where in the madrasah in the process of teaching and learning. In carrying out its duties the principal of madrasa is responsible for the quality of human resources that exist. This is so that they are able to carry out the tasks that have been given to them. In addition a principal of madrasah is also responsible for the achievement of education. This is done by moving subordinates toward the achievement of educational goals that have been established.

\section{The role of Madrasah Principal}

The principal as an educational leader is required to carry out his or her responsibilities related to educational leadership as well as possible, including as a teacher leader. ${ }^{19}$ The immediate hope of teachers, students, administrative staff, government and society is that the principal can carry out his leadership tasks as effectively as possible to realize the vision, mission and objectives embedded in optimizing the school, while also paying attention to the development of individuals and organizations. The role of a leader, will be very decisive where and what will be the organization in the lead. So with the presence of a leader will make the organization into a unity that has the power to grow and grow to become larger. Similarly, the principal of a madrasah as a leader in formal education has a very important role in the empowerment of education personnel. The school in achieving the vision and mission of education should be supported by the ability of the principal in running the wheel of his leadership. Although the appointment of the principal is not done carelessly, even appointed from an experienced teacher or may have long served as deputy principal of madrasah, but not necessarily make the principal become professional in carrying out its duties. Various cases still indicate that many madrasah heads are glued to administrative matters that can be delegated to administrative personnel. In the implementation of his work the principal is a hard job that requires extra ability. ${ }^{20}$

In performing its duties as a formal leader of an educational institution, the principal or madrasah should at least be able to function as an educator, manager, administrator, supervisor, leader, innovator and motivator.

a. Principal as an educator

In performing its function as an educator, the principal must have appropriate strategies to improve the professionalism of his or her education personnel. Creating a conducive climate, encouraging the citizens of the school, providing encouragement to all educational personnel, and implementing an interesting learning model. In the role of educator, the principal must strive to instill, promote, and enhance at least four kinds of values: mental, moral, physical and artistic coaching for teachers and staff in their leadership environment. ${ }^{21}$

${ }^{14}$ Wahjosumidjo, 1999, Kepemimpinan Kepala Sekolah, Tinjauan Teoritik dan Permasalahannya, Jakarta: PT Rajagrafindo Persada, p. 81.

${ }^{15}$ Ngalim Purwanto, 2007, Administrasidan Supervisi Pendidikan, Bandung: PT Remaja Rosdakarya, p. 26.

${ }^{16}$ N.A. Ametembun, 1975, Kepemimpinan Pendidikan, Malang: IKIP Malang, p. 1-2.

${ }^{17}$ Departemen Pendidikan dan Kebudayaan Republik Indonesia, 1988, Kamus Besar Bahasa Indonesia, Jakarta: Balai Pustaka, p. 420, 796.

${ }^{18}$ Wahjosumidjo, 1999, op.cit,p. 83.

${ }^{19}$ Sulistyorini, 2006, Manajemen Pendidikan Islam, Surabaya: Elkaf, Surabaya, p. 133.

${ }^{20}$ E.Mulyasa, 2005, Menjadi Kepala Sekolah Profesional, dalam Konteks Menyukseskan MBS dan KBK, Bandung: Remaja Rosdakarya, p. 98.

${ }^{21}$ Ibid., p. 99-100. 
1) Mental coaching is to foster educational personnel about matters relating to the attitude of mind and character. In this case the principal should be able to create a conducive climate so that every educational staff can perform the task in a professional manner.

2) Moral coaching is to foster educational personnel about matters relating to the good or bad teachings about an act, attitude, and obligation in accordance with the tasks of each educational staff. The principal must try to give advice to the entire school community.

3) Physical coaching is to nurture educational personnel about matters relating to physical condition or body, health, and their appearance outwardly. The head of a professional school should be able to provide encouragement for educators to engage actively and creatively in various sports activities, whether which is programmed in schools and organized by surrounding communities.

4) Artistic coaching is to foster educational personnel about matters related to human sensitivity to the art of beauty. This is usually done at the end of the school year.

\section{b. Principal as manager}

Management is a process of designing, organizing, leading and controlling the efforts of organizations with all its aspects in order to achieve organizational goals effectively and efficiently. ${ }^{22}$ The principal as a manager has a decisive role in school management, the success of school goals can be influenced by how the principal performs management functions. The management functions are Planning, organizing, actuating, and controlling. ${ }^{23}$

In order to perform its roles and functions as a manager, the principal must have appropriate strategies to empower educational personnel through cooperation or cooperation, provide opportunities for education personnel to improve their profession, and encourage the involvement of all education personnel in various activities that support the school program. ${ }^{24}$

Firstly, to utilize education personnel through cooperation or cooperation, it is intended that in improving the professionalism of education personnel in school, the principal should prioritize cooperation with education personnel and other parties involved in carrying out activities. As principal managers must be willing and able to utilize all school resources in order to realize the vision, mission and achieve goals. The principal must be able to deal with school issues, analytical, and conceptual thinking, to be a mediator in solving the problems faced by his subordinate education personnel, and to make satisfactory decisions for all parties.

Second, to provide opportunities for educational personnel to improve their profession. In this case the principal must be democratic and provide an opportunity for all education to develop their potential optimally. For example, provide opportunities to improve their profession through various upgrades, workshops, seminars, training, and workshops in accordance with their respective fields.

Third, encouraging the involvement of all education personnel, it is intended that the principal should strive to encourage the involvement of all educational personnel in school activities (participatory). The role of the principal, who runs his function as a manager, as revealed by Wahjosumidjo:

1) The role of interpersonal relationships,

2) Informational roles, and

3) As a decision maker.

Of the three roles of the principal as the manager, it can be described as follows:

1) Interpersonal roles

a. Figurehead, means symbol

The principal is considered the school symbol. Therefore a principal should always be able to maintain selfintegrity so that his role as a school symbol does not tarnish the good name of the school.

b. Leadership

The principal is a leader who reflects the responsibility to mobilize all existing resources in school, so that it can give birth to work ethics and high productivity to achieve goals.

c. Liaison

\footnotetext{
${ }^{22}$ Nanang Fattah, 2000, Landasan Manajemen Pendidikan, Bandung: Remaja Rosdakarya, p. 1.

${ }^{23}$ Abdullah Munir, 2008, Menjadi Kepala Sekolah Efektif, Jogjakarta: Ar-Ruzz Media, p. 16.

${ }^{24}$ E. Mulyasa, 2007, Menjadi Kepala Sekolah Profesional,Bandung: Remaja Rosdakarya, p. 103-104.
} 
The principal becomes the link between the interests of the school and the environmental interests outside the school. While internally the headmaster's connecting function becomes an intermediary tool between teachers, other school staff, and students, to obtain information from various parties in order to achieve educational success.

2) Informational roles

a. As a monitor. Principals always make observations on the environment, because of the possibility of information that affect the school.

b. As a disseminator.The principal is responsible for disseminating and distributing information to teachers, school staff, and parents.

c. Spokesman.The principal disseminates information to the outside environment as it deems necessary.

d. As a Desicional roles

(1) Entrepreneur, The school principal always tries to improve the school's performance through new thinking ideas and surveys to study issues that arise in the school environment.

(2) People who pay attention to disturbance (Disturbance Handler). The principal must be able to anticipate the disruption arising by taking into account the situation and the accuracy of the decision taken.

(3) The person who provides all the resources (A resource allocater). The principal is responsible for determining and examining who will obtain or receive the resources provided and shared. The sources include; human resources, funds, equipment, and various other school resources.

(4) A negotiator roles. The principal must be able to hold talks and deliberations with outsiders to establish and meet needs. ${ }^{25}$

The principal as a manager must know the tasks that must be carried out, as stated by Wahjosumidjo, among others, as follows: ${ }^{26}$

(1) Principals work with and through others. This means that the principal behaves as a communication channel within the school environment (as channel of communication within theorganization).

(2) The principal is responsible and accountable. The principal acts and is responsible for everything that the subordinates do. Actions committed by teachers, staff, students, and parents can not be separated from the responsibilities of the principal.

\section{Implementation of Education and Training of Madrasah Principals at Religious Training Center of Semarang}

Training is a process of continuing education and training implementation for anorganization so that employees who attend training will develop their career and work activities in developing, improving employee's work behavior, preparing employees for more complex and difficult positions, preparing stafff or develop their work activities.

The principal is a functional teacher who is assigned to lead a school in which the learning process is organized, or where there is an interaction between the teacher and the lesson. The term of educational leadership contains two meanings in which the word "education" explains in what field and where that leadership takes place and at the same time becomes the nature and characteristics of what the leader must have. According to HadariNawawi "leadership is the ability to move, motivate and influence people to be willing to performaction actions directed to the achievement of goals".

The position of principal when in association with professional understanding is a form of commitment of members of the profession to always improve the competence that aims for the quality of its performance in running and leading all the resources that exist in a normal school / madrasah to want to work together in achieving the goal. Being a professional headmaster is not easy, because there are several conditions and criteria that must be met, for example, a principal must have certain standards such as general qualifications and special qualifications, and must have certain competencies.

\footnotetext{
${ }^{25}$ Wahjosumidjo, 1999, op. cit, p. 90-92.

${ }^{26}$ Ibid., p. 97-99.

${ }^{27}$ Hadari Nawawi, op.cit.
} 


\section{RELIGIOUS TRAINING CENTER OF SEMARANG}

1. General description

Religious Training Center of Semarang Address:Jl. Temugiring Banyumanik Semarang Telp./Fax: (024) 7472551 Semarang 50261. Website: www,bdksemarang.kemenag.go.id Email:bdk_semarang@kemenag.go.id. Religious Training Center of Semarang and Religious Technical Training Officers of Semarang at the is establishment based on the Decree of the Minister of Religious Affairs No. 45 of 1981, since the Training Center began to execute the task of sincerity, and within the first 6 years of office movement as much as 3 times:

1) March 2, 1982 has one office with the Regional Office of Ministry of Religious Affairs of Central Java Province.

2) From February 3, 1983 to October 1, 1986, based on Jl. Ronggolawe West Semarang, the building belongs to the Perwanida Regional Office of Religious Affairs of Central Java Province.

3) October 2, 1986 until now based on Jl. Temugiring Banyumanik Semarang.

At that time, the Religious Training Center of Semarang felt unable to perform its main duty and function optimally, because it was constrained by various rules and provisions of caliber which limited the authority of the task of self-actualization.

With the issuance of the Decree of the Minister of Religious Affairs No. 1 of 2001 on the Organizational Structure and Working Arrangement of the Ministry of Religious Affairs, is a new era of Strengthening the Tasks and Functions of Institutional Training for Religious Training Center of Semarang as the only training institution in the area that has work area in the environment Ministry of Religious Affairs of Central Java Province and Special Province of Yogyakarta.

\section{Main Duties and Functions}

PMA No. 59 of 2015 (article 2) states that the duty of the Religious Training Center is to organize education and training of administrative and technical personnel of education and religion, in accordance with their respective working areas.

To carry out the duties as mentioned above, the Religious Training Center organizes functions:

1) Formulation of vision, mission and policy of Religious Training Center;

2) Implementation of education and training of administrative personnel, and religious technical personnel;

3) Services in the field of religious education and training;

4) Preparation and presentation of reports on the implementation of the tasks of the Religious Training Center;

5) Implementation of coordination and partnership development with the organizational unit / work unit within the Ministry of Religious Affairs, and local government, as well as other related institutions.

\section{Organizational structure}

Organizational Structure of Religious Training Center of Semarang(Lamp. PMA 59 of 2015)

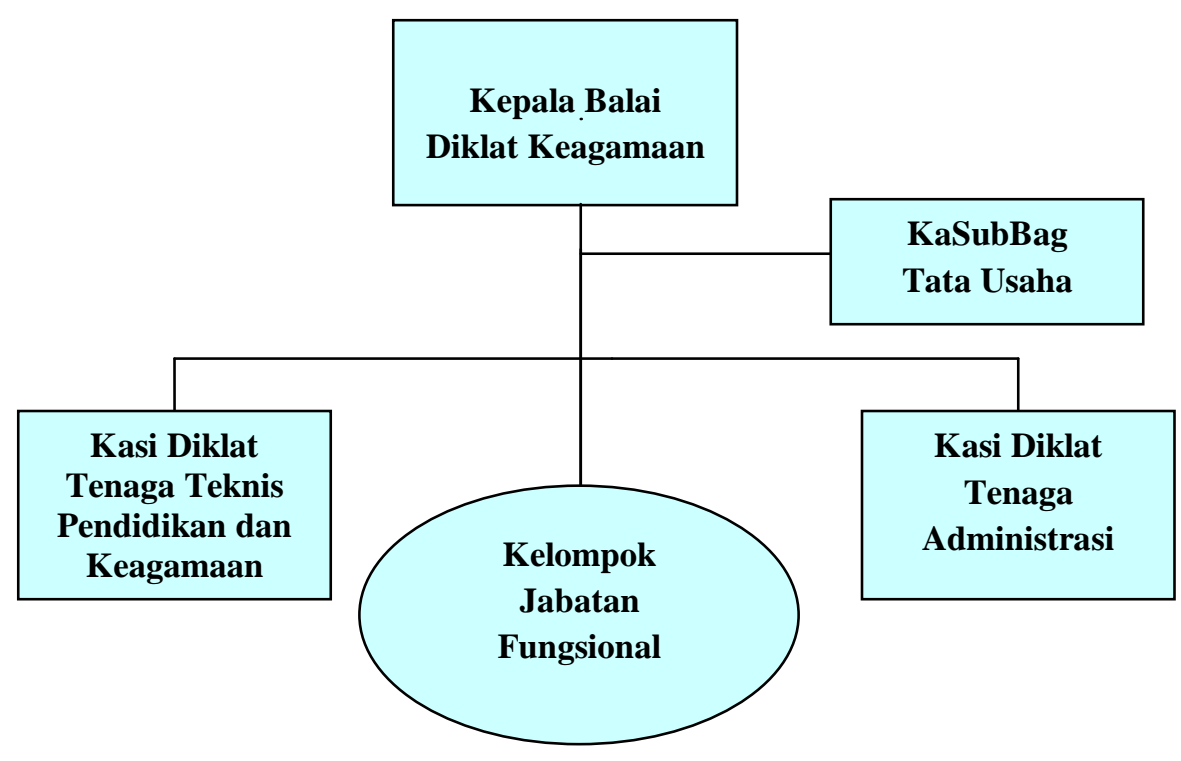




\section{E. DISCUSSION OF RESEARCH RESULTS}

The results of the research and interviews of the training participants on June 12, 2017 which were encapsulated by the researchers on the Development of Education and Training Model (DIKLAT) for Madrasah Principals at the Training Central Religious of Semarang in 2017:

a. Implementation of Current Training

1) Planning

Planning in an activity is an important factor even more functional technical training program. Good planning in accordance with aspects of employment needs and interests can help the organizers in carrying out its activities with integrated so as to achieve maximum results.

a) Preparation

Preparation of training center for the program is good. The value of this good indicator can we from the performance of the committee in the process of reception, re-list participants, placement of participants in the well-equipped lodging. Training participants can carry out all activities successfully and successfully fulfilled. Including facilities and infrastructure needed by the students are all filled.

b) Material

Training materials, especially on the group of cawas in accordance with future supervisors tupoksi. This means that this material provides initial capital for prospective supervisor stop lunge in the actual place of duty. The materials are given as the provision of the training participants in the process of holding technical functional positions that will be carried.

c) Widyaiswara

The widyaiswara in accordance with their tupoksi and professionally in delivering the material. This can be seen from the competence that is owned by the Widyaiswara in deliveringthe material. Widyaiswara convey the material by providing optimal performance motivation to achieve professionalism in work. Widyaiswara professionally demonstrates good competence by looking at significant staffing levels. Expose training materials with an interesting method and involve all the training participants so that what is delivered in the training can be well received by the training participants (interview, date, 12June, 2017).

2) Implementation Process

a) Preparation for the implementation of the training, always ready and responsive is preceded by the morning apple participants as a form of commitment to the Nation and the State of Indonesia and demonstrate discipline in duty and confidence in carrying out the tasks, to the needs of training and training participants.

b) Participants follow the training with full responsibility and thoroughness as a form of seeking knowledge and carrying out the duties.

c) The material is conveyed, the material in accordance with the material tupoksi in need of the prospective supervisor.

d) Widyaiswaranya who convey with familiar, soft, smart, creative, innovative and intelligent (interview, date, 12June, 2017).

b. Output Current Training On:

1) Organizing committee, good service but needs to be improved in the future, especially on consumption for training participants.

2) The menu is requested to vary and sufficient, because sometimes when we do the last activity the last ever did not get the same part with another.

3) The material presented is good in terms of the content of the material, and in accordance with the needs of supervisors training and training participants. And can be the capital in the field, but still need to improve again.

4) Training participants can absorb what is presented by the widyaiswara as knowledge and experience needed in terms of the supervision of Religious education at the district / city level.

5) The impression of Widyaiswara, all Widyaiswara friendly and living in a family environment, so in training centers that take a long time felt at home. Widyaiswara can be a source of insipration and knowledge in selfdevelopment and professionalism in work (interview, date, 12 June, 2017).

c. Future Development of About Training:

1) The organizing committee must be optimized again, and reach all the personnel needs in the environment, so that no more employees who have not or have not followed the training both functional and quality improvement.

2) Training materials are developed in a more conducive and interactive atmosphere that increasingly makes the participants more interested and alwayscurious. 
3) Participants may transmit knowledge in the workplace and be instituted in accordance with their duties and functions in order to improve education in Indonesia in general and Islamic education at their respective workplaces.

4) Widyaiswara, if it can not only involve Widyaiswara Religious Training Center only but give opportunity to other education center. So ourway of thinking can be colored along with different view points of different institutions. With the difference being a comparative study of science that builds synergies to complemen teach other and complement the perfection of an education program for training participants (interview, date, 12 June, 2017).

d. Development of Education and Training of Madrasah Principals at Religious Training Center of Semarang

1) The Organizing Committee must be optimized again. And reach all the needs of staffing in the environment, so no more employees who have not or have never followed the training both functional and quality improvement.

2) Training materials are developed in a more conducive and interactive atmosphere that increasingly makes the participants more interested and always curious.

3) Participants may transmit knowledge in the workplace and be instituted in accordance with their duties and functions in order to improve education in Indonesia in general and Islamic education at their respective workplaces.

4) Widyaiswara, if you can not only involve the Widyaiswara Religious Training Center but give the opportunity to other education center. So the way of thinking we can be colored along with different view points of different institutions, with the difference is a comparative study of science that builds synergies complement each other and complement the perfection of an education program and laithan for training participants.

e. Discussion of Research Development Results of Education and Training Principal of Madrasah Aliyah in Central Religious Training Center of Semarang.

Development of Education and Training Model (DIKLAT) Principal of Madrasah At Religious Training Center of Semarang on 2017. Training that has been carried out, at the time of carrying out the comparison between what has been done and at the time and its evaluation and how the development of the Madrasah Principal training in the Religious Training Center of Semarang can be viewed in the following recapitulation.

Tabel. 1:- Assessment of the Training Committee and Widyaiswara on the Participants of Madrasah Aliyah Principal TrainingThat has been done until the end.

\begin{tabular}{|l|l|l|l|l|l|l|}
\hline \multirow{2}{*}{ No } & Pelaksanaan Diklat Kep. MA & Nilai \\
\cline { 3 - 6 } & tahun 2016 & Test & Sikap & Produk & Jumlah & Rata-rata (IP) \\
\hline 1 & Angkt I tgl13-22 Juli 2016 & 68.86 & 84.50 & 83.65 & 237.01 & 79.00 \\
\hline 2 & Angkt 2 tgl 25 Juli-03 Agst 2016 & 74.50 & 82.65 & 79.86 & 237.01 & 79.00 \\
\hline & tahun 2017 & & & & & \\
\hline 1 & Angkt 1 tgl 5-15 Juni 2017 & 69.86 & 88.50 & 81.65 & 240.01 & 80.00 \\
\hline 2 & Angkt 2 tgl 05-15 Juni 2017 & 78.65 & 88.86 & 76.50 & 244.01 & 81.34 \\
\hline
\end{tabular}

Tabel. 2:- Assessment of Training Participants to the Organizer at the Madrasah AliyahPrincipal Training which has been implemented in the Year 2016-2017.

\begin{tabular}{|c|c|c|c|c|c|c|}
\hline \multirow[t]{2}{*}{ No } & \multirow{2}{*}{$\begin{array}{l}\text { Pelaksanaan Diklat Kep. MA } \\
\text { tahun } 2016\end{array}$} & \multicolumn{5}{|l|}{ Nilai } \\
\hline & & $\begin{array}{l}\text { Penyeleng } \\
\text { gara }\end{array}$ & Pengelola & Pelayanan & Jumlah & $\begin{array}{l}\text { Rata-rata } \\
\text { (IP) }\end{array}$ \\
\hline 1 & Angkt I tgl 13-22 Juli 2016 & 85.73 & 84.43 & 86.30 & 256.46 & 85.49 \\
\hline 2 & Angkt 2 tgl 25 Juli-03 Agst 2016 & 87.34 & 86.70 & 83.42 & 257.46 & 85.82 \\
\hline & tahun 2017 & & & & & \\
\hline 1 & Angkt 1 tgl 5-15 Juni 2017 & 88.26 & 86.55 & 84.62 & 259.43 & 86.48 \\
\hline 2 & Angkt 2 Tgl 05-15 Juni 2017 & 87.72 & 85.11 & 87.53 & 260.36 & 86.79 \\
\hline
\end{tabular}

Tabel, 3:- Assessment of Training Participants to the Widyaiswaraat the Madrasah AliyahPrincipal Trainingwhich has been and is being implemented in 2016-2017.

\begin{tabular}{|c|c|c|c|c|c|c|}
\hline \multirow[t]{2}{*}{ No } & \multirow{2}{*}{$\begin{array}{l}\text { Pelaksanaan Diklat Kep MA } \\
\text { tahun } 2016\end{array}$} & \multicolumn{5}{|l|}{ Nilai } \\
\hline & & Penguasaan & Metode & Sikap & Jumlah & Rata- \\
\hline
\end{tabular}




\begin{tabular}{|l|l|l|l|l|l|l|}
\hline & Materi & Pembel & Perilaku & & $\begin{array}{l}\text { rata } \\
\text { (IP) }\end{array}$ \\
\hline 1 & Angkt I tgl.13-22 Juli 2016 & 87.78 & 88.96 & 87.43 & 264.17 & 88.06 \\
\hline 2 & $\begin{array}{l}\text { Angkt 2 tgl 25 Juli-03 Agst } \\
2016\end{array}$ & 86.54 & 87.70 & 89.66 & 263.90 & 87.97 \\
\hline & tahun 2017 & & & & \\
\hline 1 & Angkt 1 tgl 5-15 Juni 2017 & 87.87 & 88.72 & 88.45 & 265.04 & 88.35 \\
\hline 2 & Angkt 2 tgl 05-15 Juni 2017 & 85.96 & 88.78 & 89.43 & 264.17 & 88.06 \\
\hline
\end{tabular}

\section{Testing Data}

Testing the data aims to get the results of the distribution of data obtained so that it can specify the data analysis tool that can be done. The data test is done by using shapirowilk test, with the reason that the data analyzed is data with small sample ( $<50$ data). Data normality is obtained based on the sign value, where when the resulting sign value is greater than $0.05(5 \%)$, it is said to be normally distributed.

Tabel 4:-Tests of Normality

\begin{tabular}{|l|l|l|l|l|l|l|}
\hline & \multicolumn{4}{|l|}{ Kolmogorov-Smirnov $^{3}$} & \multicolumn{2}{l|}{ Shapiro-Wilk } \\
\cline { 2 - 7 } & Statistic & Df & Sig. & Statistic & df & Sig. \\
\hline Test 2016 & .354 & 6 & .018 & .772 & 6 & .032 \\
\hline Sikap 2016 & .212 & 6 & $.200^{*}$ & .958 & 6 & .804 \\
\hline Produk 2016 & .157 & 6 & $.200^{*}$ & .978 & 6 & .939 \\
\hline Jumlah 2016 & .285 & 6 & .138 & .801 & 6 & .060 \\
\hline Rata-rata (IP) 2016 & .286 & 6 & .137 & .801 & 6 & .060 \\
\hline
\end{tabular}

a. Lilliefors Significance Correction

b. This is a lower bound of the true significance

\section{Data Analysis:-}

Data analysis conducted aims to obtain information about the implementation of the training of Madrasah AliyahPrincipal in 2016-2017 which carried out two forces, based on the assessment of the widyaiswara and participantsdiklat.Widayaiswara conduct assessment of test results, attitudes of participants and products. Participants conduct assessment of the implementation of training including the organization, development and services provided. Participants of training also conduct assessment of the widyaiswara related to the mastery of the material, learning methods used and attitudes and behavior Widyaiswara.

Assessment of the implementation of the training of Madrasah Aliyah Principal is done by making a comparison between the implementation of 2016 to 2017, so that in obtaining information the effectiveness of the implementation of training that has been done.

Tabel 5:- Paired Samples Test

\begin{tabular}{|c|c|c|c|c|c|c|c|c|}
\hline \multirow{3}{*}{ Paired Samples Test } & \multicolumn{5}{|c|}{ Paired Differences } & \multirow[t]{3}{*}{$\mathrm{T}$} & \multirow[t]{3}{*}{$\mathrm{df}$} & \multirow{3}{*}{$\begin{array}{l}\text { Sig. } \\
(2- \\
\text { tailed) }\end{array}$} \\
\hline & \multirow{2}{*}{ Mean } & \multirow[b]{2}{*}{$\begin{array}{l}\text { Std. } \\
\text { Deviation }\end{array}$} & \multirow[b]{2}{*}{$\begin{array}{l}\text { Std. Error } \\
\text { Mean }\end{array}$} & \multicolumn{2}{|c|}{$\begin{array}{l}95 \% \mathrm{Cl} \text { of the } \\
\text { Difference }\end{array}$} & & & \\
\hline & & & & Lower & Upper & & & \\
\hline $\begin{array}{lcc}\text { Pair test } & 2016 \\
\text { test } 2017-1 & \end{array}$ & -1.261 & 1.76417 & .72022 & - & .58972 & -1.752 & 5 & .140 \\
\hline $\begin{array}{l}\text { Pair sikap 2016-- } \\
\text { sikap 2017-2 }\end{array}$ & -1.930 & 2.84469 & 1.16134 & - & 1.05532 & -1.662 & 5 & .157 \\
\hline $\begin{array}{l}\text { Pair produk } 2016- \\
\text { produk } 32017\end{array}$ & .3566 & 2.65835 & 1.08527 & $\begin{array}{l}- \\
2.43310 \\
\end{array}$ & 3.14643 & .329 & 5 & .756 \\
\hline $\begin{array}{l}\text { Pair jumlah } 2016- \\
\text { jumlah } 42017\end{array}$ & -2.835 & 2.35955 & .96328 & $\begin{array}{l}- \\
5.31119\end{array}$ & -.35881 & -2.943 & 5 & .032 \\
\hline $\begin{array}{l}\text { Pair rata-rata (IP) } 2016- \\
\text { rata- } 5 \text { rata (IP) } 2017\end{array}$ & -.9466 & .78889 & .32206 & $-\overline{1.77456}$ & -.11878 & -2.939 & 5 & .032 \\
\hline
\end{tabular}


Based on the results of data analysis using paired samples test test obtained there is a significant difference between the results of the implementation of Madrasah Aliyah Principal education training in 2016-2017 based on the average value (IP). It is seen from the big difference of average is 0,9466 and sign value equal to 0,032 smaller than $0,05(5 \%)$.

However, when viewed from the value of each indicator, it has not showed a significant difference where the results of the test value obtained by the sign value of 0.140 , from the attitudinal value obtained by the sign value of 0.157 and from the value of the product obtained sign value of 0.756 . This means that the value of the sign is greater than $0.05(5 \%)$, so it can be said there is no significant difference in test values, attitudes and products on the implementation of Madrasah Aliyah Principal training in 2016-2017.

\section{F. CONCLUSION:-}

Based on the implementation of employee performance development through education and training according to the observations of researchers from the above description can be summed up as follows:

1. The Education and Training Model (Diklat) provides a positive response in the development of employees through the performance of employees that institutions / agencies really pay attention to the need for burden in the implementation of work and responsibilities that have been submitted to him.

2. Model development of education and training is to optimize the increase of work productivity of employees function to improve the atmosphere of organization / institution in the form of skills and job execution techniques so that the development of an employee is considered very important.

3. Employees are motivated to carry out the work and strive to increase work productivity with the development of employee competence through education and training provided to him.

\section{G. SUGGESTION:-}

In developing the model of education and training to the head of madrasah aliyah the author gives advice that:

1. The Organizing Committee must be optimized again, and reach all the personnel needs in the environment, so that no more employees who have not or have not followed the training both functional and quality improvement.

2. Training materials are developed in a more conducive and interactive atmosphere that increasingly makes the participants more interested and always curious.

3. Participants may transmit knowledge in the workplace and are developed in accordance with their duties and functions in order to improve education in Indonesia in general and Islamic education at their respective workplaces.

4. Widyaiswara, if it can not only involve Widyaiswara of Religious Training Center only but give opportunity to other education center. So our way of thinking can be colored along with different viewpoints of different institutions. With the difference is a comparative study of science that build synergies complement each other and complement the perfection of an education program and laithan for training participants. 


\section{References:-}

1. Abdullah Munir, 2008, Menjadi Kepala Sekolah Efektif, Jogjakarta: Ar-Ruzz Media.

2. Ardana, I Komang dkk, 2012, Manajemen Sumber Daya Manusia, Yogyakarta: Graha Ilmu.

3. Benny A. Pribadi, 2010, Model Desain Sistem Pembelajaran, Jakarta: Dian Rakyat.

4. Departemen Pendidikan dan Kebudayaan Republik Indonesia, 1988, Kamus Besar Bahasa Indonesia, Jakarta: Perum Balai Pustaka.

5. E. Mulyasa, 2005, Menjadi Kepala Sekolah Profesional dalam Konteks Menyukseskan MBS dan KBK, Bandung: Remaja Rosdakarya.

6. Faustino Cardoso Gomes, 2003, Manajemen Sumber Daya Manusia, Yogyakarta: Andi Offset.

7. Hani Handoko, 2001, Manajemen Personalia dan Sumberdaya Manusia, edisikedua, Yogyakarta: BPFE.

8. Henry Simamora, 2006, Manajemen Sumber Daya Manusia, edisi 2, Yogyakarta: STIE YKPN.

9. Mulyasa E., 2012, Manajemen dan Kepemimpinan Kepala Sekolah, Jakarta: Bumi Aksara.

10. N.A. Ametembun, 1975, Kepemimpinan Pendidikan, Malang: IKIP Malang.

11. Nanang Fattah, 2000, Landasan Manajemen Pendidikan, Bandung: Remaja Rosdakarya.

12. Nawawi Hadari, 2005, Metode Penelitian Bidang Sosial, Yogyakarta: Gajah Mada Univeristy Press.

13. Ngalim Purwanto, 2007, Administrasi dan Supervisi Pendidikan, Bandung: PT Remaja Rosdakarya.

14. Peraturan Menteri Agama Republik Indonesia Nomor 29 Tahun 2014 tentang Kepala Madrasah.

15. Sjafri Mangkuprawira, 2003, Manajemen Sumber Daya Manusia Stratejik, cetakan ke-2, Jakarta: Ghalia Indonesia.

16. Stephen P. Robins, 1996, Organizational Behavior: Concepts, Controversies, Applications, New York: Prentice Hall, Inc.

17. Sulistyorini, 2006, ManajemenPendidikan Islam, Surabaya: Elkaf.

18. Syafaruddin Alwi, 2001, Manajemen Sumber Daya Manusia, Yogyakarta: Strategi Keunggulan Kompetitif, BPFE.

19. Wahjosumidjo, 1999, Kepemimpinan Kepala Sekolah, Tinjauan Teoritik dan Permasalahannya, Jakarta: PT Rajagrafindo Persada.

20. Wahyusumiyo, 2002, Kepemimpinan Kepala Sekolah, Jakarta: PT Raja Grafindo Persada.

21. Yusuf Hadi Miarso, 2011, Survei Model Pengembangan Instruksional, makalah yang disampaikan sebagai bahan ajar kuliah mahasiswa S3 Program Studi Teknologi Pendidikan Pascasarjana UNJ. 